\title{
Keeping Distance from Practical Politics: A Critical Analysis of the Muhammadiyah Political Movement from the Catholic Perspective
}

\author{
Yoachim Agus Tridiatno \\ Universitas Atma Jaya Yogyakarta
}

Recieved: 15 April 2020

Revised: I2 November 2020 Published: 27 April 202I

\begin{abstract}
Abstrak:
The Muhammadiyah's stance that tends to keep distance from practical politics in line with the ideals of the founder are dynamic and crucial. The tense was very strong between those willing to be faithful to the mission and those wishing to indulge into practical politics. During this period, the elites maneuvered the political moves numerous times until its centennial years. These experiences act as lessons learned from other organizations in Indonesia. The research aims to determine the critical reflection on the political moves of Muhammadiyah from the Catholic perspective. It uses the Catholic Social Teachings as a reflective tool to determine alternative insights on Muhammadiyah.
\end{abstract}

Keywords:

Muhammadiyah; political movement; catholic social teaching; the church

\section{Introduction}

illions of Indonesians that watched the movie "Laskar Pelangi" (The
Rainbow Soldiers) in 2008 seemed to lawfully declare
Muhammadiyah an Islamic social organization that highly idealizes education. The movie, with the 1970 s social settings, describes the exceptionally simple SD Muhammadiyah Gantong (Muhammadiyah Elementary School in Gantong), in Belitong Island, which struggled to exist irrespective of its extremely limited facilities. The school was given an ultimatum by the local Department of Education to be shut down because the population of students was extremely few and it lacked adequate facilities that support the functioning of the system. The only female teacher, Bu Muslimah, ignored all forms of enticement from friends to leave the school and search for other ones. The teacher patiently accompanied and educated the nine students, enrolled in the school, and motivated them to dream of reaching the beautiful rainbow in the blue sky. However, with the aid of the liberating educational model, the teacher successfully instilled selfconfidence in the students. In addition, students won the inter-school competition on

\section{Korespodensi:}

Universitas Atma Jaya, Jl. Babarsari No.44, Janti, Caturtunggal, Kec. Depok, Kabupaten Sleman, Daerah Istimewa Yogyakarta 55281.

Email: tridiatno@yahoo.com. 
intellectual skills. This led to the recognition of SD Muhammadiyah Gantong, by the local government, and it was therefore permitted to exist and continue its dedication to education.

The extremely significant progress of the school in recent days seems to manifest the high idealism of Muhammadiyah as portrayed by the movie. The other advancements include aspects of health care, social works, and the publishing of religious propaganda (dawah). The glorious ceremony for commemorating its centennial anniversary in 2012 manifested its power by embracing millions of members and this covered 4322 branch offices throughout Indonesia.

In the context of its centennial anniversary, the movie titled "Sang Pencerah" (The Enlightener) which reported the biography of Kyai Hadji Ahmad Dahlan, the founder of Muhammadiyah, was produced and millions of moviegoers enjoyed the process. Subsequently, it portrayed the fact that Muhammadiyah is an enormous Islamic social organization in Indonesia which is extremely influential in the political aspect.

In this situation, it is understandable that the consistency of the founder - to be in distant from practical politics - is truly a great challenge. Furthermore, before the Tanwir (yearly meeting) which commenced on March 5 and ended on 8, 2009 in Bandar Lampung, Ahmad Syafii Maarif, the former head of Muhammadiyah (20002005), was quoted:

(The Council of Muhammadiyah in Ujung Pandang 197I emphasizes that Muhammadiyah needs to be distant from all forms of political powers. The constitutional line is relevant and needs to be kept in the recent political situation of our nation, which is not healthy enough. Therefore, elites of the Islamic movement have to be skilful and wise in delivering political statements in order not to tarnish the image of Muhammadiyah which is perceived as a large tent of the nation (Translated by author, Kompas, 5 March, 2009)

From the beginning, Muhammadiyah was perceived as a religious and social movement, and not a political movement. Although the political process was negotiable, its statute clearly prohibited the process, therefore, members holding any political positions are expelled from the board. Consequently, the leaders played political games which automatically made it possible for Muhammadiyah to be recognized as an organization.

Historically, it has been involved in several political moves despite being criticized by its members (Karim, 1986; Nur \& Pramono U., 2000; Pakkanna \& Ahmad, 2005). Efforts to ensure that Muhammadiyah is involved in practical politics have been persistent, even, till the 2009 General Election. Therefore, it is a relevant topic that needs to be carefully studied. Setiawan (2012) reported the political pragmatism of Muhammadiyah. Efendi (2017) stated the phenomenon of the fragmentation of Muhammadiyah elites in the 2009 presidential elections. 
Based on this background, this research seeks to offer a critical reflection from the Catholic perspective. It is divided into various sections, namely introduction, clarification of the scope and method of study, a sketch of Muhammadiyah's political moves, critical reflection from the Catholic Perspective, the high politics of Muhammadiyah, and finally, the conclusive aspect.

\section{Scopes and Method of Study}

The ability to distance oneself from practical politics implies not getting involved in its affairs. For example, it is not the duty of Muhammadiyah leaders to intervene in government policies. In addition, Islamic organizations are considered as being crucial. On the contrary, as a religious and social organization, Muhammadiyah strives to ensure the wellbeing of its members, however, to achieve that, it is of paramount importance for Muhammadiyah to get involved in the political arenas in its broadest sense. Subsequently, it causes leaders to engage in practical politics to realize effective outcomes. Conversely, the founder stated that Muhammadiyah need not get involved in practical politics. Therefore, for the past hundred years of its history, Muhammadiyah ensured that its feet were not trapped in the wrong stones.

The political moves reported in this study refer to activities, strategies and statements formally delivered by Muhammadiyah or its leaders ranging from the formative periods (1912 - 1923) to the reformation era (1998). Based on this view, Amien Rais, the former head of Muhammadiyah, (1995-2000), when interviewed by a journalist, Sahid, stated that Amien's words as a leader are not personal, it also includes Muhammadiyah.

"I am the Muhammadiyah's leader, which means that my voice is automatically that of Muhammadiyah. Therefore, when I speak, it is my personal idea, and similar to the voice of Indonesia is that of Soharto, PDI's is Megawati's. PPP's is Ismail Hasan Metareum's, and Golkar's is Harmoko's “(Suwarno, 200o).

In accordance with Amien Rais's terms, this research is centred on the fact that the moves of the leaders also encompass that of Muhammadiyah. In this instance, Khoiri (2013) studied (the Islamic thoughts of Muhammdiyah in the political regulation (pemikiran politik hukum Muhammadiyah). Khoiri further reported that some legal products relating to the Muhammadiyah figures in the House of Representative, are the Undang-Undang No. I4/1970 tentang Kekuasaan Kehakiman (Law Number I4/1970 concerning Yudicial Power), Undang-Undang Nomor I/1974 tentang Perkawinan (Law Number I/I974 regarding Marriage), Undang-Undang Nomor 7/1989 tentang Peradilan Agama (Law Number 7/1989 concerning Religious Courts) which are considered as the works of Muhammdiyah. The struggles of these figures to ensure that the Islamic teachings are included in the legal products are similar to that of the Muhammadiyahs'. Even, Khoiri reported that irrespective of the fact that Muhammadiyah is not directly involved in practical politics, in fact, its figures play the games. 
Related to this issue, Al-Hamdi (2012) reported that the elites of Muhammadiyah are classified into four types. First, the transformative-idealistic type refers to those that promote and encourage Muhammadiyah to indulge in socially transforming the society in accordance with the level of Islamic idealism and practices. Second, the moderate-idealistic type refers to those that encourage Muhammadiyah to achieve Islamic idealism which is contextualized in a contemporary situation. Third, the realistic-critical type refers to those that incite Muhammadiyah to be critical in bringing universal Islam in the pluralistic of Indonesian society. Fourth, accommodative-pragmatic refers to those that take up cooperative positions, as well as compromises some beneficial parties. Conclusively, these four types of elites, of course, manifests in Muhammadiyah.

Similarly, Efendi (20I7) reported that the fragmentation of Muhammadiyah elites, particularly during the 2009 Presidential Election, is classified into five types, namely the fundamentalist politics, passive moderate, active, khittoism, and politics. In short, the political moves of the elites represent the motives of Muhammadiyah.

By research methods, ihis research is a qualitative study, and it offers a critical reflection of the Catholic perspective based on the experiences of Muhammadiyah in striving to be distant from practical politics in line with the ideals of the founder. It is a critical reflection, in the sense that it "offers alternative ways of knowledge" (Morley, 2008). It is "a reasoning that tends to occur beyond established and accepted social processes" (Smith, 20II). It involves ethical, political, and social issues, which are different from personal, interpersonal, and contextual domains (Smith, 20II).

In accordance with the adoption of the critical reflection analysis, this research does not compare Muhammadiyah organization to the Catholic Church, based on two reasons. Firstly, there is no such organization in the Catholic Church. Irrespective of the fact, that there are, indeed, groups such as Wanita Katolik Republik Indonesia (Catholic Woman of Indonesian Republic), Perhimpunan Mahasiswa Katolik Republik Indonesia (The Catholic Student Association of the Republic of Indonesia), etc. They are purely social organizations which do not possess hierarchical links to the Catholic Church. Secondly, this research does not intend to analyze Muhammadiyah based on the Catholic parameters. Instead, it seeks to discover new knowledge and insights to "uncover the silent cognitive acts that govern the lives of individuals" (Foucault in Mortari, 2015) or in accordance with Habermas "to move beyond merely reproducing this action" (Smith, 20II). This study tries to incite people to perceive Muhammadiyah as a social and religious organization which purely struggles for humanity without considering any other interest. Therefore, Muhammadiyah is always faithful to the ideals of the founder.

This research adopts the Catholic Social Teachings based on critical reflection. These are teachings of Pope Leo XIII, (from I898 to 1903), to the ruling Pope Francis, including the conciliar document, Gaudium et Spes (the Joy and Hope) which analysis social issues namely labor, economy, family, political community, war and peace, as 
well as the environment (Spitzer, 2017). Furthermore, the Pontifical Council of Justice and Peace published a comprehensive document of the Catholic Social Teaching entitled Compendium of the Social Doctrine of the Church (2004). These teachings, mostly address Catholics globally, however, it also influences the social discourses of the world at large.

Regarding the data related to the political moves of Muhammadiyah which is the objective of this study, information and opinions were realized from certain books, such as the works of Alfian (1989), Alwi Shihab (1998), Syaifullah (1997), Suwarno (2000) and articles written by Andi Setiawan (2012), Ridho Hamdani (2012), Nispul Khoiri (2013), and David Efendi (2017). Furthermore, in order to confirm certain ideas concerning the development of an Islamic state, one of the scholars from Muhammadiyah named Zuly Qodir was personally interviewed.

\section{Muhammadiyah's Political Moves in a Sketch}

\section{During the Formative Periods from 1912 to 1923}

Muhammadiyah established arenas for its activities during the formative period, from I9I2 to I923, as stated in its Statute (article 2) thereby spreading the religious teachings of the prophet Muhammad to the people residing in Yogyakarta, as well as improving the members. These goals are realized through education, propaganda or tablikh, and the use of mosques for praying and publishing pamphlets (article 3). The Muhammadiyah organizational structure encompasses of the School Division (Bahagian Sekolahan), Propaganda Division (Bahagian Tabligh), Publishing Division (Bahagian Taman Pustaka), and the Division for Improving the People's Miseries (Bahagian Penolong Kesengsaraan Oemoem). It is quite evident that Muhammadiyah is not involved in the political arena.

Agus Salim suggested that it needs to be involved in political affairs during the annual meeting held in I9I8. Agus a politician from Syarikat Islam, proposed the need for Muhammadiyah to be transformed into a political organization. Consequently, Agus' rhetoric earned the admiration of the audiences. Ahmad Dahlan successfully convinced Salim and the others to forget about this idea (Syaifullah, 1997). Dahlan stated the essence of Islam and ways to actualize it globally. During that era, the Indonesian economy was poor, the only appropriate way to actualize Islam is to enhance the socio-economic and educational sector. This caused Ahmad Dahlan to be firm with the idea to rebuild Muhammadiyah as a social and religious organization centred on economics, education, and health.

\section{The Case of Jakarta Charter}

In preparation of the Indonesian Independence, the Japanese announced the formation of an Investigating Committee for Preparatory Work (Badan Penyelidik Usaha-usaha Persiapan Kemerdekaan Indonesia), also referred to as BPUPKI, in March 1945. Its 43 members were the Javanese leaders from various schools of thought. 
Additionally, Ki Bagus Hadikusumo, Kahar Muzakkir, and Sukiman were from Muhammadiyah. On the May 3I, I945, meeting of BPUPKI, Ki Bagus Hadikusumo addressed the idea concerning the founding of an Islamic state in response to the speech previously delivered by the nationalist groups held during the BPUPKI, on May 3I, 1945. It was further explained that socio-historically Islam has been in existence for at least six centuries in the country. Those that fought for it were Muslim, and this shows that the spirits of Islam was alive in the heart of the people. Ki Bagus Hadikusumo was anxious about the fact that it need not be the foundation of the state, because assuming that were the case, majority of the people that were Muslim need not have the spirit to fight for the country (Syaifullah, 1997). A day after, precisely on June Ist 1945, Soekarno delivered a speech concerning the five principles which are the philosophical foundation of the state referred to as Pancasila. They include belief in God, Nationalism, humanitarianism, social justice, and democracy (Ricklefs, 2008). In order to compromise the nationalist and Islamic groups, Pancasila was accepted as the foundation of the state in accordance with "seven words" which were included after the first principle, which is the belief in God. They are "dengan kewajiban untuk menjalankan syariat Islam bagi pemeluk-pemeluknya" or the obligation for adherents of Islam to carry out Islamic law, and It was called Jakarta Charter or Piagam Jakarta.

Christian groups represented by Latuharhary were unwilling to accept the Jakarta Charter because they were afraid of its implication for non-Muslims. However, Agus Salim reported that their safety was guaranteed by the tolerance of $90 \%$ Muslims and in accordance with the customary law. On the contrary, Ki Bagus Hadikusumo suggested that the last three words needs to be abolished "bagi pemeluk-pemeluknya" or for adherents of Islam, in order to ensure that the law is favorable, for both Muslims and non-Muslims (Syaifullah, 1997). Sukarno reminded them that the formulation was due to the compromise between the nationalist and Islamic groups. After lengthy deliberation, Ki Bagus Hadikusumo suggested that the last three words "bagi pemelukpemeluknya" be abolished.

Conversely, Abikusno from "Panitia Sembilan" or "Nine Committee" offered a lengthy explanation and requested that all members of BPUPKI uphold peace and unity. Lastly, Radjiman, the head of BPUPKI, told Ki Bagus Hadikusumo that they accepted Jakarta Charter, which was signed on July 22, 1945. Therefore, it shows the persistence of Ki Bagus Hadikusumo in fighting for the Islamic bases of the state.

The other issue was centered on the requirements needed to become the President and Vice President of the state, as cited in chapter 4, verses 2 of the drafted Constitution. Abdul Wahid Hasyim stated the addition "yang beragama Islam" or those that embraced Islam to become the President and Vice President of the state. It was supported by Abdul Kahar Muzakkir and later on by Ki Hadi Bagus Hadikusumo. Even, Muzakkir emotionally gave an ultimatum that it is better to abolish all the words 
of Allah from the draft, assuming it did not clearly state "those that embrace Islam". Ki Bagus Hadikusumo supported Muzakkir and asked the audience whether it was better to accept or to abolish Islam. According to Syaifullah (I997), it is inseparable from the state. Sukarno stated that all audiences, including the non-Muslims, need to accept the suggestion of Muzakkir and Ki Bagus as a form of sacrifice. Finally, the meeting ended with all members of the BPUPKI agreeing to the proposition.

The description shows the extent of the political move made by the Muhammadiyah leaders. They were bent on actualizing their dreams by persistently fighting for Islam. Therefore, one needs to imagine the manner the leaders and Islamic groups in general, were disappointed when the Jakarta Charter and the criteria for becoming the President and Vice President is based on the fact that the individual needs to be a Muslim were dropped by the Preparatory Committee of Indonesian Independence (Panitia Persiapan Kemerdekaan Indonesia/PPKI). This occurred during a PPKI meeting held on August 18, 1945, due to the message of the Japanese navy regarding the disapproval of Indonesians Christians in the eastern part with an ultimatum not to join the state. However, before the formal meeting, Hatta called Ki Bagus Hadikusumo, Wahid Hasjim, Kasman Singodimedjo, and Teuku Muhammad Hasan to analyze the "seven words" and the criteria required for becoming a President and Vice President which were disapproved by the Christians. Hasan agreed to abolish it despite not being involved in BPUPKI. Wahid was not present, conversely, Kasman Singadimedjo, a new member of PPKI, was suddenly invited for the pre-formal meeting. Kasman was not aware of the issue because he was not a member of BPUPKI. However, Kasman persuaded Ki Bagus to agree to the reduction of the "Islamic character" Jakarta Charter (Syaifullah, 1997). This event affected the Islamic figures and Indonesian Muslims in general. It became the precedent for the critical character of Muhammadiyah's political moves.

\section{Muhammadiyah and Masyumi}

In October 3, 1945, the government requested that Indonesians form a political party, Muhammadiyah and other Muslim organizations founded the Masyumi Party that same year. Its objectives (Majelis Syuro Muslimin Indonesia or Council of Indonesian Muslim Associations), according to the 1945 Statute, are "to support the sovereignty of Indonesian Republic and Islam, as well as to realize the Islamic ideals in the state affairs". However, the formulation of these objectives has been changed to "Realizing Islamic teaching and law in an individual's life, society, and the Indonesian Republic" since 1954 (Deliar Noer, 1987, Syaifullah, 1997). The role of Muhammadiyah in Masyumi is evident in the number of board members. Consequently, "since its foundation in 1945 till its dispersal in 1960, Muhammadiyah cadres dominated the board of Masyumi at an average of 55\%" (Ghazali, 2005). Abd. Rohim Ghazali stated 
that the involvement of cadres from the Ist to I8th Cabinet with average of I s.d.I.27\%. Furthermore, when the NU left the party, Muhammadiyah was the strongest supporter of Masyumi until President Soekarno dissolved it in 1960.

The involvement of Muhammadiyah was debatable, because firstly, it dominated the Masyumi Board in 1945, although, in 1949, it decreased to 27, 26\%. Even, the slogan was changed from "berjuang melalui Masyumi dan beramal melalui Muhammadiyah" meaning "to struggle and do good through Masyumi and Muhammadiyah" respectively to "beramal dan berjuang dalam Islam" which simply means "to do good and struggle through Islam". Subsequently, it shows that Islam is more insightful than the institution, therefore some Muhammadiyah's figures were unwilling to get involved in Masyumi. During the 1953 Muktamar, a group of youths proposed that Muhammadiyah be transformed into a political party. Responding to the proposal, the following theories were established namely (I) Muhammadiyah is still perceived as an Islamic organization, (2) practically, it does not imply that Muhammadiyah is changed to a political party (Syaifullah, 1997).

However, when Masyumi was dissolved by President Soekarno, its leaders were put in jail, and Muhammadiyah was indirectly affected irrespective of the fact that it was not disintegrated. The reformist, including Muhammadiyah figures, was pulling out from their political positions. After the disintegration of Masyumi, Muhammadiyah became more focused on Islamic propaganda (dakwah), thereby leading to an increase in its followers and the branches, and in the 1970s and 80s, it became the basis for Islamic revivalism (Hefner, 2007).

At the initial phase of the Soeharto government, there were efforts to revive the Masyumi, although, it was not approved by the Soeharto. Muhammadiyah sent representatives to the President requesting for the revival of Masyumi. It was turned down, although, the Soeharto suggested that it needs to be transformed into a political party. However, it was refused by Muhammadiyah (Sujarwanto, Nashir, \& Ruslikarim, 1990). According to Mulyadi Djojomartono, there was an initiative to revive Partai Islam Indonesia or Indonesian Islamic Party founded by Muhammadiyah leaders in I958 (Nasir, 1988), although it was not realized. In addition, the Panitia Tujuh or the Seven Commission was founded by Partai Muslimin Indonesia (Parmusi) or Indonesian Muslimin Party. It was approved by the President on February 20, I968, while H. Djarnawi Hadikusumo and Lukman Harun, both from Muhammadiyah were the head and general secretary respectively. Conversely, due to the internal conflict initiated by John Naro, the President intervened by appointing H.M. Mintardja, S.H., an ordinary person from Muhammadiyah, as the head of Parmusi on November 20, I970 (Tamara, 1988). In 197I, Parmusi lost the General Election, because Parmusi had only $7,365 \%$ of the votes. On the contrary, when the government implemented the merging of parties, Parmusi belonged to the Development Unity Party (Partai 
Persatuan Pembangunan/PPP), while H.M. Mintardja, S.H. became the head of the central board (Nasir, I988).

\section{The New Order Era}

During the New Order era, the government initiated depoliticization, which simply implied that people were allowed to participate in political affairs minimally. This is usually referred to as "floating mass", and the government was extremely firm in dictating its policy to the citizens, therefore there was no room for negotiation, Muhammadiyah was also included in this instance. As earlier stated, there was an increase in social and religious activities, however, it does not mean that there were no political moves made by Muhammadiyah. I mention the case of the Law of Marriage 1974, the Law of System of National Education 1989, the fatwa or edict on the prohibition of Muslim to attend the Christmas celebration. It is important to report the two events which manifested the anger of Muslim against the New Order government.

The first was the riot which occurred on January I5, 1974 the masses "protested against corruption and the increasing role of foreign corporations in the Indonesian economy for several months. The government blamed the protest and riots on leaders of the two outlawed political parties, namely Masyumi and the Indonesian Socialist Party" (Woodward et al. 2007). The second was Tanjung Priok event that took place in I984 when preachers delivered sermons and protested against the government's campaign of Pancasila sebagai Asas Tunggal (Pancasila as the single basis for social organization). On September I2, 1984, approximately I500 people rallied from the mosque in Tanjungpriok to the police station to demand the release of those detained on September 8, 1984, conversely, I4 people died in this event. There was no remark regarding the involvement of Muhammadiyah in the two tragedies.

Regarding Asas Tunggal Pancasila, according to A.R. Fachruddin, the head of Muhammadiyah I968-1990", stated that"no problem was witnessed in Muhammadiyah, although Pancasila is not the only principle. Therefore, it is evident that Muhammadiyah tends to maintain its identity as an Islamic organization, because it was not abolished by the government. Muhammadiyah is an Islamic movement amar ma'ruf nahi munkar, which functions based on the Quran and Hadits, including the principles of the Pancasila, which is stated underneath (H.A.R. Fachruddin, 1984). It is only centered on the establishment of Undang-Undang tentang Organisasi Sosial Kemasyarakatan or the Law on Social Organization No. 8, 1985. It adopted the concept of Asas Tunggal Pancasila in the 4Ist Muktamar in Solo from December 7 to II, 1985 (Muhammadiyah, 2005).

The 1974 Undang-Undang Perkawinan or the Law of Marriage is similar to the Jakarta Charter case, which involved the Christian and nationalist contra Islamic groups (Shihab, 1998). In 1973, the government implemented the draft relating to the Law of Marriage, which seems to offer Christian principles on this regulation. It seems that the Christian group proposed the draft a long time ago because, in February I969, the Catholic faction in the legislative body had addressed the issues regarding the law 
of marriage. This was stated in chapter I0, verse 2, and it was centered on mixed marriage among those from different races, ethnicity, and religion. In the Muslim community, this type of marriage, particularly among those from different religions, is prohibited, whereas in Christianity it is permitted. Therefore, the Islamic group decided to change the draft of this verse to "Marriage is considered as legal, when it is performed in accordance to the law of religion and belief of the couple" (UU Perkawinan 1974). The formulation of this verse, became problematic for the Christians and others because it means that there is no possibility for a mixed marriage, and this was a severe problem for non-Muslim, in a country where the majority were Muslims.

The Christian stance, as stated by the representative of the Catholic faction was not to refute Islamic regulations on marriage, rather the objective of applying religious principles in the civil law. According to the Muslim groups, this position shows the hindrance caused by applying Islamic spirit in the legal products, as reported in the case of Jakarta Charter. The strong critics of Islamic groups, particularly Muhamadiyah figures, led to the approval of the 1974 Law of Marriage, which is effective till date.

The similar instance occurred when the government established the 1989 Law of National Education System. The problem was reported in chapter 28, verse 2 concerning the fact that religious education for the students' needs to be delivered by a teacher with a similar belief. It means that Christian schools need to offer an education based on the belief of the students as well as employs teachers with a similar belief. Consequently, for Christian schools with special missions, this verse is problematic because it loses its identity. The protest was launched, while the President approved the law. In this circumstance, Lukman Harun from Muhammadiyah was firm in proposing this idea. A similar incident occurred when the government launched the 2003 Law on System of National Education as an amendment of the previous one.

In 198I, Dr. Hamka, the great man in Muhammadiyah, that headed the Majelis Ulama Indonesia or Indonesian Ulama Council (MUI) delivered fatwa or edict concerning the prohibition of Muslims to attend Christmas celebrations. This caused the government to be disappointed because it tends to lead to disharmony between Muslims and Christians. The government persuaded MUI to cancel the edict, however, Hamka was firm about their position. Hamka preferred to resign as the head of MUI rather than cancel the fatwa.

\section{Muhammadiyah and the 1998 Reformation}

Amien Rais was the most important figure behind the reformation movement in 1998. Firstly, Amien's idea regarding the succession of the national leader on the Tanwir Muhammadiyah in Surabaya was launched from December II to I3, 1993. Amien was elected as Muhammadiyah's leader on Muktamar 43rd in Banda Aceh based on certain criteria concerning the general election held in 1997, the neutrality of 
Muhammadiyah, including the development of potentials for the social welfare. Responding to these recommendations, Muhammadiyah under Amien Rais leadership criticized the government in order to realize the social welfare of the people. During the Tabligh Akbar or great meeting of the young Muhammadiyah held on September I 1996, Amien Rais appreciated the success of the New Order, while the shortcomings were reminded. Tanwir Muhammadiyah in Banjarmasin, which occurred from the 13 to 15 December 1996, recommended ten points regarding socioeconomic-political lives and the hope for success during the 1997 general election. Subsequently, on January 9, 1997, Amien Rais started to criticize the government relating to Busang and Freeport, which were considered as unconstitutional. These critics led to Amien's resignation from the Ikatan Cendekiawan Muslim Indonesia (ICMI) or the Bound of Indonesian Muslim Intellectuals position. In April 1997, Amien Rais, the leader of Muhammadiyah's Central Board stated the eight items which led to the success of the New Order, however, two of them, namely corruption-collusion, and socio-economic gaps between the poor and rich failed.

Conversely, I998 was the peak of Amien Rais's movements in criticizing the government. Corruption and collusion of the government were criticized based on the Cabinet built by the elected President Soeharto during a special meeting of Consultative Assembly held in March. The Cabinet was considered as "lelucon politik" or political comedy, because Tutut, Soeharto's daughter, was appointed as the Minister of social affair, and Soeharto's cronies held other positions. Amien tried to incite nonviolent people to cause a reformation. This showed that Amien was involved in movements to resign Soeharto from the presidency, even until the 1999 general election in order to build a new government thereby replacing the New Order held by B.J. Habibie.

Is there a possibility that Amien Rais represented Muhammadiyah? In certain instances, Amien acted as the head of Muhammadiyah, while in some others as an individual. As stated earlier, Amien Rais reported that Amien acted both as Muhammadiyah's leader and an individual. As an organization, Muhammadiyah belonged to Badan Kordinasi Umat Islam or Islamic People Coordination Body which suggested that Soeharto needs to resign from the presidency. The 1998 Tanwir Muhammadiyah held in Semarang from 5 to 7 July 1998 stated some points, namely Muhammadiyah need not be become or, build a new party, and its involvement in politics is an individual responsibility of its members (Hamdani Kurniawan). According to AM, Fatwa during the Tanwir Semarang recommended Muhammadiyah to build a new party (A.M. Fatwa). Furthermore, at the end of Tanwir, Amien Rais announced that Syafii Maarif was the leader of the new party. Partai Amanat Nasional, which was later called PAN or National Mandate Party, was declared on August 23, I 998 in Senayan Jakarta and Amien Rais resigned from the position in Muhammadiyah to become the head of PAN. 
PAN is not a political party, in fact, all branches of Muhammadiyah works for PAN. In the 1999 general election, it realized 7,I2 \% or 7,53 million voters from approximately 28 million members of Muhammadiyah. This shows that these members are rational and not emotional voters. This led to diverse reactions from the youths to change the principle of PAN not as an open party rather as a Muhammadiyah's party (Ali Rizkatillah Audah). Till date, PAN is an open party, and it successfully brought Amien Rais to the chair of Majelis Permusyawaratan Rakyat (The People Council of Indonesian Republic) from 1999 to 2004. Furthermore, during the 2004 General Election, the failure of PAN in realizing significant voters and in bringing Amien Rais to the presidency was considered as being the fault of Muhammadiyah which failed to ultimately play a political game. However, during the 2009 General Election, Angkatan Muda Muhammadiyah (The Youth of Muhammadiyah) founded Partai Matahari Bangsa (The Sun of Nation Party) as an alternative of the Partai Amanat Nasional.

\section{Critical Reflection from the Catholic Perspective}

\section{The Catholic Social Teachings}

The Catholic Church, as a religious institution, is a human community centered on the divine and spiritual elements because of the belief in God as a Transcendent Being, and the incarnation of Jesus Christ, the son accompanied forever by the Holy Spirit. Through its human delineation, it spreads truth and grace to all (Lumen Gentium, 1964). It constitutes of members all over the globe. Therefore, the joys, hopes, griefs and anxieties of those in the world are also similar to the experiences felt by Church members ( Gaudium et Spes, 1964a).

Regarding politics, the Catholic Church teaches that "the political community and itself are mutually independent and self-governing" (Gaudium et Spes, 1964a). The Church serves the spiritual needs of the faithful, and it is incompetent in delivering the social, economic, and political affairs which belong to the services of the political community. This is due to human nature, family, and other civil communities that are unable to achieve "a truly human life by unaided efforts." They need a broader community which provides them with the realization of a common good. Therefore, they set up political arenas to achieve a common good which embraces the conditions of the social life in order for men, families, and associations to adequately and readily attain their perfection (Gaudium et Spes, 1964a). Furthermore, due to the flow of human nature, the political community needs to be governed in accordance with the divine and moral order for the sake of a common good. The Church encourages Christians to get involved in political affairs based on their capacities actively. This made it possible for the Church members to be able to work together while the political authorities strive for a common good. Therefore, they are postulated to obey them, as 
far as they work for the common good. Although, assuming they don't, they are bound to indulge in civil disobedience (Gaudium et Spes, 1964a).

With regards to the participation of the Church's members in the political community, there is need to clarify the distinction between "the tasks which Christians undertake, individually or as a group, and their responsibilities as citizens guided by the dictates of a Christian conscience, and the activities, in unison with their pastors, which is carried out in the name of the Church" (Gaudium et Spes, 1964a). In the hierarchical structure of the Church, there are three classifications of minister, namely the clerics, religious, and laity. The clerics consist of the bishop of Rome that is the Pope, priests, and deacons, which are the leaders of the Church and responsible for the religious and spiritual affairs (Lumen Gentium, 1964). The religious are those responsible for sharing testimonies concerning the fact that it is impossible to transform and offer the world to God without the spirit of the beatitudes. The laity, by their vocation, seeks the kingdom of God by engaging in temporal affairs as well as ordering them according to the plan of God. They live in the world, that is, in each of the secular professions and occupations (Lumen Gentium, 1964). All temporal affairs, included practical politics are the task of the laity.

As an institution, the Church is not involved in practical politics. The clerics as the leaders and representatives of the Catholic Church "are forbidden to assume public offices which entail a participation in the exercise of civil power" (Canon Law of the Catholic Church). Its mission does not include political, economic, or social order, rather it is a religious one, and based on that, the Church tends to interfere and influence the world according to the moral and divine law. Furthermore, through moral exhortations, it provides moral advice for the good of human life in the world. Furthermore, assuming social conditions are demanding, the Church carries out concrete charity works, particularly for the weak and needy (Gaudium et Spes, 1964).

In the history of the Church, there were moral exhortations from the Catholic Social Teachings which truly echoes in the human world, for example, Rerum Novarum or the New Things (I89I), and the encyclical letter of Pope Leo XIII, which taught about the value of work, wages, and right to private property. Pacem in Terris or Peace in the World (1963), the encyclical letter of Pope John XXIII, which incited the world peace and respect to human rights. Populorum Progressio or Development of the People (1967), the encyclical letter of Pope Paul VI, which encourages respect and the solidarity of the rich nations as well as the others. Humanae Vitae or Human Life (1968), the encyclical letter of Pope Paul VI, which reaffirms the Catholic Teaching concerning married love, responsible parenthood, and rejection of most methods of birth control. Laborem Excercens or Through work (I98I), the encyclical letter of Pope John Paul II, which teaches about man's dignity in work including subordination to work, the primacy of the worker overall conditions which constitute the world of labor, the rights of humans to determine the factors of all economic, technological and 
productive processes. Deus Caritas Est or God is Love (2006), the encyclical letter of Pope Benedict XVI, which illustrates the concept of love in three types namely eros, agape, and logos and its implementation in the human life. Laudato Si or Praise to the Lord (2015), the encyclical letter of Pope Francis, which proclaims that the universe is a common home that needs to be maintained by all human beings.

Moral exhortations of the Church is mostly addressed by Catholics globally, however, they also have an indirect effect on the societies. Besides, the Pope, as the leader of the Catholic Church, also delivers messages on World Peace Day, which is held on every Ist of January. Additionally, the Pope usually addresses humanitarian calls every time the pontiff visits various countries. The Abu Dhabi Declaration is an example of the document from the apostolic journey of Pope Francis to the United Arab Emirates. This Document on Human Fraternity for World Peace and Living Together was signed by Pope Francis and Eminence the Grand Imam of Al Azhar, Dr. Ahmed At-Tayyeb. It encourages a strong relationship and harmony among peoples against radicalism and its effects.

Subsequently, due to the fact that the position of the Vatican City is recognized as an international state, the calls of the Pope as its leader also has a great influence on all the leaders in the world. It is important to note that the Pope's speeches are always centered on universal humanitarian problems, for example, poverty, refugees, war, and human rights. The Pope never speaks solely on matters of interest to the Catholics, thereby emphasizing on the fact that the Church is not involved in practical politics.

The Church recognizes the autonomy of the state as the political community, which is in charge of the common good. On the contrary, it claims the recognition of the state regarding religious freedom, thereby causing the faithful to observe their rights to religious life (Gaudium et Spes, 1965). Therefore, the Church refutes secularism which proclaims the moral autonomy of the state and the abolition of faith from the public sphere as well as subordination (Ivereigh \& K.Griffin, 20II: 2).

\section{The Cases of People Power in 1986 and El Salvador in 1980}

Some concrete cases give the impression that the Catholic Church is involved in practical politics. The most popular incident was the non-violent People Power's Revolution in the Philippines on February 25, 1986. Jaime Cardinal Sin, Archbishop of Manila and leader of the Catholic Church in the Philippines, called on Catholics to join the non-violent demonstration in EDSA Avenue to oust the dictator President Marcos from the presidency. This was due to the fact that Marcos' government was unable to strive for the common good, conversely, with the enactment of the Martial Law, Marcos committed absolute power that is contrary to the human values. Marcos was responsible for the murder of, Benigno Aquino, at the airport on 2I August 1983 when the former senator and Marcos' opponent returned to the Philippines from exile in the United States. Marcos further, carried out the most deceitful election on February 7 , 
I986 which proclaimed Marcos as the winner against the woman candidate, Corazon Aquino, the wife of the late Benigno Aquino.

Because of the calling of Jaime Cardinal Sin, thousands of Catholics which consist of priests, nuns, and laypeople gathered in EDSA Avenue to express their protests in prayers and rosaries in front of the tanks. Praise God, that the peaceful demonstration was successful because it led to the withdraw of tyrant Marcos from the presidential seat. Subsequently, Corazon Aquino took the presidential oath of office and was proclaimed as the IIth president of the Republic of the Philippines on February 25, 1986 (History, n.d.).

It seems that Jaime Cardinal Sin, the leader of the Catholic Church, was involved in the political demonstration and was carried out for defeating Marcos's regime, which demeaned humanity. Therefore, for the sake of defending universal humanity, Jaime Cardinal Sin got involved in practical politics that did not oppose Jaime's position as the Church leader. Jaime mobilized peaceful demonstrations in the form of prayers and rosaries. In this situation, "it is a matter which touches on the Gospel, core freedom and rights (such as the right to life, or religious freedom), or the principles of Catholic social teaching. In these circumstances, the Church not only needs to speak out, it has a duty to uphold" (Ivereigh \& K.Griffin, 20II).

A similar incident occurred in the case of Oscar Romero, the Archbishop of San Salvador (Biography, n.d.). Oscar Romero was shot died by a paid assassin while leading Mass in the chapel of Divine Providence Hospital on March 23, 1980. In the morning before, Oscar spoke to the soldiers and policemen, "Oscar begged, implored, and ordered them.... In the name of God, to stop the repression!" Oscar severally demanded that the President carry out an investigation concerning the numerous killings and disappearances, however there was no response. In 1979, the situation in El Salvador was worst when the military were killing the Salvadorian civilians, particularly those that strive for justice such as teachers, nuns, priests, including Romero's good friend, Fr. Rutilio Grande. The number of killings even reached 3000 per month, and to protest against the repression of the military, Oscar Romero delivered consolatory sermons broadcasted on the radio every Sunday, and consoled the people with hope that they need not suffer and die in vain.

In conclusion, the Catholic Church does not get involved in practical politics. It is competent in the religious arenas where its moral teachings and speeches are delivered. Consequently, through religious missions, it tends to permeate the world at large for infusing moral and spiritual values. It is only in an urgent situation, which involves the degrading of humanity, that the Catholic Church intervenes carries out charity work particularly for the weak, and when necessary undertakes non-violent movements to defeat the inhuman ruler.

\section{The High Politics of Muhammadiyah}


Based on the Catholic perspective, it is extremely significant that the dynamics of Muhammadiyah shows a strong tense between getting involved and being distant from practical politics. On the contrary, several cadres of Muhammadiyah were extremely consistent in its missions as an Islamic propaganda or dakwah organization. Subsequently, several members also presumed that it is the moment for Muhammadiyah to get involved in practical politics which tends to be more effective in enhancing the spirit of amar ma'ruf nahi munkar or struggle for goodness and eliminate the bad (Setiawan, 20I2). Furthermore, in that dynamics, Muhammadiyah has an amazingly firm foundation which proposes that it is a social and religious organization, and not into politics.

A milestone was built in Muktamar Ujung Pandang, also referred to as khitah Makasar 197I (Makasar Agreement 197I) which stated that "Muhammadiyah adalah gerakan Islam yang beramal dalam segala bidang kehidupan manusia dan masyarakat dan tidak berafiliasi dengan organisasi politik apapun" or "Muhammadiyah is an Islamic movement which encompasses of all human fields and society without affiliating with any political organization" (Syaifullah). It revised khitah Ponorogo 1969 (Ponorogo Agreement 1969) which stated the two ways to realize the ideals of Muhammadiyah which is political channel obtained through a political party while the social one is through a non-political organization.

"cita-cita perjuangan Muhammadiyah hanya bisa diwujudkan melalui dakwah Islam dengan saluran secara serentak, yaitu saluran politik, alatnya adalah organisasi politik atau partai politik, dan saluran masyarakat, alatnya adalah organisasi nonpolitik atau organisasi kemasyarakat"

(The ideals of Muhammadiyah struggle is only realized through Islamic dakhwah with political (party) and social (non-political organizations) channels as its instrument) (Syaifullah, 1997).

This is, firmly realized with the spirit of building a high politics rather than a low one. It means that Muhammadiyah prefers to deliver moral messages regarding social and political problems, rather than get involved in practical politics (Rais, 1995). According to Haedar Nashir, high politics is perceived as the neutrality of Muhammadiyah because of its interest, thereby ensuring the supremacy of moral values, and control mechanism in order that its individuals are not trapped in practical politics (Putro, 1998). Consequently, some points were reported as a critical reflection of the political moves earlier described.

First, Ahmad Dahlan was the follower of Muhammad Abduh (I849-1905), the Islamic reformer that focused on developing religious and theological knowledge through ethics and education to achieve moral betterment of the people. Abduh was a 
philosopher, theologian and expert in language and history (Suwarno, 2000). Dahlan did not follow the other reformer, namely Jamaluddin al-Afghani (I839-I897) that was a politician and thinker. The two reformers had similar external (responding to the critics from the West regarding Islam in social, political, and intellectual fields), and internal goals (injecting the new spirit of understanding Islam in accordance to the contemporary challenges) in their struggles. In respect to the methods, Al-Afghani adopted a political means, whereas Abduh, applied a social and educational approach.

Dahlan's choice to follow Abduh was ideal in the Indonesian context at that time, and Dahlan's principle was based on the essence of Islam as rahmatan lil'alamin (as the blessing for the universe). Dahlan prefered to struggle for humanity in the broadest sense rather than in political arenas. Meanwhile, Muhammadiyah allowed its members to select their political organization to actualize their aspirations, although as a religious and social institution was distant from political powers, which implies that it is not affiliated to any party. Therefore, Ahmad Dahlan cooperated with the government. Ahmad got a government subsidy for erecting more Muhammadiyahs (Steenbrink).

Second, as an Islamic reformer, Muhammadiyah was extremely firm in defending Islam. The persistent struggle of Ki Bagus Hadikusumo in the case of Jakarta Charter, the struggle for the 1974 Marital Law, and other legal products Khoiri (2013) is the manifestation of this firmness. Conversely, in the context of inclusivity and pluralism of Ahmad Dahlan that was extremely open to dialogue, even to those with other beliefs (Rustam, 20I6), the persistence seem to be inconsistent, for example, based on Chapter 2 verse I of the 1972 Marital Law which regulates that "marriage is legal when it is performed in accordance to religious policies and belief of the couple" it becomes a serious problem particularly between a Muslim and those with different beliefs. The global era which is open for all humanity to develop personal relation towards marriage bond with people from different races, ethnicity, and beliefs, the limitation of the 1974 Marital Law Chapter 2 verse I does not provide a feature of inclusivity and pluralism.

Third, the political move by Muhammadiyah in accordance with the dissolution of Masyumi and the blacklisted figures was quite an experience. It was inconsistent with the approach adopted by Dahlan, which was cooperating with the government in order to enhance the social and religious movements. In fact, the issue of critically criticizing the government occurred some years back when Muhammadiyah criticized Goeroe-Ordinannatie of the Dutch government. Alfian reported that this situation was due to "the inherent negative attitude of the colonialism establishment towards Islam” (Alfian, 2008). Although, get involved with a political party is not in line with the spirit of high politics. Zuly Qodir, a Muhammadiyah scholar, during a personal interview reported that "Muhammadiyah does not have the slightest idea that Indonesia needs to be converted to an Islamic state 
by applying its law, and it was final. The Islamic principles need to be manifested in the social life. Therefore, the spirit of amar ma'ruf nahi munkar or the struggle for goodness in order to eliminate the bad is always persistent."

Fourth, some political moves of Muhammadiyah still offer a strong impression about its personal interests. Learning from the concerns of Ahmad Dahlan for the universal humanity particularly those marginalized and oppressed (Rustam, 2016), Muhammadiyah as a modern Islamic organization should focus more on the universal problems of humanity in the broadest sense, rather than minor cases such congratulating other religious communities during their holidays or the determination of the Eid date. Several matters are related to humanity in the broadest sense and need to be strived for by Muhammadiyah. Furthermore, assuming Muhammadiyah focuses on the issues of universal humanity, it is able to realize the idea of high politics. Therefore, it tends to be successful in bringing Islam as rahmatan lil'alamin or as the blessing for all human beings. It is considered as the ideals of Ahmad Dahlan when Muhammadiyah was founded.

\section{Conclusion}

Muhammadiyah is a social and religious movement or gerakan dakwah. It indulges in high politics rather than the practical one which adheres to the supremacy of moral values and Islamic spirit “amar ma'ruf nahi munkar" or the struggle for goodness and elimination of the bad. In addition, it consistently adheres to the idea of the founder, K. H. Ahmad Dahlan. It also affirms the thesis that separating religion from politics or integrating both is unsuccessful. Muhammadiyah adopted a moderate approach, based on using religious principles to enlighten politics (Adeney-Risakotta, n.d.). In accordance with the idea of Nakamura Mitsuo, which stated the challenges of Muhammadiyah, to democratize Indonesia, based on the civil society, is on the appropriate track (Nakamura, 2005). James L Peacock appreciated the success of Muhammadiyah in distancing itself from politics (Peacock, 1986).

Some political moves strongly give the impression that Muhammadiyah only strives to realize personal goals, rather than universally in the broadest sense. Muhammadiyah is intended to be successful in realizing the ideals of the founder, assuming it adopts the spirit of high politics.

The need to separating religion from practical politics seems to be appropriate in Indonesia, because the West appreciates it for its success in developing religious harmony. During the International Seminar in Roma, Indonesia was used as a global model for religious harmony (Olla, 2009). Its success was mostly centered on separating religion from politics. The religious violence occurred mostly due to the confusion between religion and politics. In this regard, the intention of Muhammadiyah to be distant from political powers is an example that needs to be imitated by other religious movements. 


\section{Acknowledgment}

Thanks to some colleagues at Atma Jaya University who provided suggestions and criticism for this paper.

\section{Funding}

The author does not receive funding assistance for research from any party.

\section{References}

Adeney-Risakotta, B. (n.d.). Agama dan Politik: Interaksi dalam Sejarah Dunia Umumnya dan Indonesia Khususnya" (Religion and Politics: Inteeraction in the World History in General and Indonesia in Special). Gema Edition, 59, 7-26.

Al-Hamdi, R. (20I2). Dinamika Islam dan Politik Elit-Elit Muhammadiyah Periode I998-20I0. Jurnal Studi Pemerintahan, 3(I).

Alfian, A. (2008). Menjadi Pemimpin Politik. Jakarta: PT Gramedia Pustaka Utama.

Biography, S. O. R. (n.d.). Caritas Australia. Retrieved from http://www.caritas.org.au/docs/primary-school-resources/oscar-romerobiography.docx

Catholic, C. (2004). Pontificium Consilium de Iustitia et Pace, Pontifical Council for Justice, \& Peace. Compendium of the Social Doctrine of the Church: USCCB Publishing.

Efendi, D. (2017). Fragmentasi Politik Muhammadiyah: Studi Tentang Elite Muhammadiyah dalam Pemilu Presiden Tahun 2009 (Political Fragmentation of Muhammadiyah: Study on the Elites Muhammadiyah in the 2009 President Election), (May). Retrieved from https://www.researchgate.net/publication/317025909

Ghazali, A. R. (2005). Khittah Muhammadiyah digugat" (Muhammadiyah Basic Principles Accused). In Muhammadiyah Menjemput Perubahan (Muhammadiyah Anticipates Change) (Mukhaer Pa). Jakarta: Kompas dan P3SE STIE Ahmad Dahlan Jakarta.

Hefner, R. W. (2007). Politik Multikulturalisme-Menggugat Realitas Kebangsaan. Kanisius. History, P. (n.d.). No Title. Retrieved from https://www.philippine-history.org/edsapeople-power-revolution.htm

Ivereigh, A. A., \& K.Griffin. (20II). Catholic Voices: Putting the Case for the Church in the Era of 24-Hour News. London: Darton: Longman and Todd.

Karim, M. R. (1986). Muhammadiyah dalam Kritik dan Komentar (Muhammadiyah in the Critics and Comments). Jakarta: C.V. Rajawali.

Khoiri, N. (2013a). Pemikiran Politik Hukum Islam Muhammadiyah" (Islamic Law Political Thinking of Muhammadiyah) in Asy-Syi'ah. Jurnal Ilmu Syariah Dan Hukum, 47(I). 
Khoiri, N. (2013b). Pemikiran Politik Hukum Islam Muhammadiyah. Asy-Syi'ah. Jurnal Ilmu Syariah Dan Hukum, 47(I).

Morley, C. (2008). Critical Reflection as a Research Methodology. Knowing Differently: Arts-Based and Collaborative Research Methods, 265-280.

Mortari, L. (2015). Reflectivity in Research Practice: An Overview of Different Perspectives. International Journal of Qualitative Methods, I-9.

Muhammadiyah, P. (2005). Ensiklopedia Muhammadiyah. Jakarta: PT Raja Grafindo Perkasa.

Nakamura, M. (2005). Muhammadiyah Faces the Challenge of Democracy. In Muhammadiyah Menjemput Perubahan (Muhammadiyah Anticipates Changes) (Mukhaer Pa). Jakarta: Kompas dan STIE Ahmad Dahlan Jakarta.

Nasir, T. (1988). Sejarah Politik Islam Orde Baru" (Political History of Islam in the New Order). Prisma.

Nur, A., \& Pramono U., T. (2000). Muhammadiyah “Digugat”. Reposisi di Tengah Indonesia yang Berubah (Muhammadiyah Accused. Reposition in the Midst of the Changing Indonesia). Jakarta: Kompas.

Olla, P. Y. (2009). Melirik Indonesia sebagai Model Kerukunan (To See Indonesia as a Model of Harmony).

Pakkanna, M., \& Ahmad, N. (2005). Muhammadiyah Menjemput Perubahan: Tafsir Baru Gerakan Sosial-Ekonomi-Politik. P3SE STIE Ahmad Dahlan Dan Penerbit Buku Kompas, Jakarta.

Peacock, J. L. (1986). Gerakan Muhammadiyah Memurnikan Ajaran Islam di Indonesia (Purifying the Faith: Muhammadiyah Movement in Indonesia Islam ). Jakarta: Penerbit Cipta Kreatif.

Putro, A. A. (1998). Konsepsi High Politics dalam Kerangka Pemikiran Politik Muhammadiyah (The Concept of High Politics in the Frame of Muhammadiyah Political Thought). Universitas Muhammadiyah Malang.

Rais, A. (1995). Moralitas Politik Muhammadiyah (Political Morality of Muhammadiyah). Yogyakarta: Dinamika.

Ricklefs, M. C. (2008). Sejarah Indonesia Modern I200-2008. Jakarta: P.T Serambi Ilmu Semesta.

Rustam, I. (20I6). Tantangan ALKI dalam Mewujudkan Cita-cita Indonesia sebagai Poros Maritim Dunia. Indonesian Perspective, I(I), I-2I.

Setiawan, A. (2012). Muhammadiyah sebagai Kelompok Kepentingan dalam Politik Nasional Pascaorde Baru Tahun I998-20Io. Politika: Jurnal Ilmu Politik, 3(2).

Shihab, A. (1998). Membendung Arus: Respons Gerakan Muhammadiyyah Terhadap Penetrasi Misi Kristen di Indonesia. Bandung: Mizan.

Smith, E. (20II). Teaching Critical Reflection. Teaching in Higher Education, I6(2).

Spitzer, Robert, S. . (20I7). A Summary of Catholic Social Teaching. Retrieved from https://www.magiscenter.com/wp-content/uploads/20I7/II/A-Summary-ofCatholic-Social-Teaching.pdf 
Sujarwanto, Nashir, H., \& Ruslikarim, M. (1990). Muhammadiyah dan Tantangan Masa Depan: Sebuah Dialog Intelektual. Yogyakarta: Tiara Wacana.

Suwarno. (2000). Muhammadiyah, Islam, dan Runtuhnya Orde Baru. Studi tentang Perubahan Perilaku Politik Muhammadiyah Periode 1995-I998 (Muhammadiyah, Islam, and the Fall of the New Order. A Study on the Political Behavioral Change of Muhammadiyah Periods 1995-1998). Universitas Gajah Mada.

Syaifullah. (1997). Gerak Politik Muhammadiyah dalam Masyumi. Pustaka Utama Grafiti.

UU. (IAD). Undang-Undang Republik Indonesia Nomor I7 tahun I974 tentang Perkawinan.

VI, P. P. (1964a). Gaudium et Spes (The Joy and Hope). Retrieved from http://www.vatican.va/archive/hist_councils/ii_vatican_council/documents/vatii_cons_1965I207_gaudium-et-spes_en.html

VI, P. P. (I964b). Lumen Gentium. Retrieved from https://www.vatican.va/archive/hist_councils/ii_vatican_council/documents/vatii_const_I964II2I_lumen-gentium_en.html

\section{About Author}

Yoachim Agus Tridiatno is lecturer in Universitas Atma Jaya Yogyakarta. The author have researchs area around social-humaniora and theology. 